\title{
Krajina k ochutnání
}

\section{Monika J anáková}

Envigogika 15 (1) - Inspirace / I nspirations

Published/ Publikováno 22. 11. 2020

DOI: $10.14712 / 18023061.609$

\begin{abstract}
Abstrakt
Aktuální téma regionální kuchyně a léčitelství je v článku diskutováno z hlediska možných způsobů zajištění potravy z místních zdrojů a samozásobitelství. J de o formu, která oproti globálnímu potravinářskému průmyslu méně zatěžuje životní prostředí. Lokální potravinové zdroje tradičně úzce souvisí $s$ regionální kuchyní a léčitelstvím. Autorka se $v$ tomto kontextu věnuje planým léčivým a jedlým rostlinám. Vychází z historicky doložených zpráv o využívání planě rostoucích rostlin na území České republiky, a pokouší se mapovat souvislosti mezi člověkem a jeho prostředím, které se projevují znalostmi o samotných rostlinách i způsobech jejich využití. Zájem o plané rostliny se dnes opět vrací díky environmentálním akcentům, a to z hledika nutnosti péče o krajinu v širších souvislostech.
\end{abstract}

\section{Klíčová slova}

Plané rostliny; samozásobitelství; místní kuchyně; léčitelství

\begin{abstract}
Recently, the theme of regional cuisine and healing is again relevant, especially in the context of local foods and self-sufficiency. Securing food from local sources is less harmful to the environment compared to the global food industry. The sources of local food are traditionally related to regional cuisine and medicine. In this context, the article deals with wild medicinal plants and wild edible plants. The author works with historically documented sources that map the occurrence of wild plants on the Czech territory; on this basis she outlines relationships between man and his environment. These relationships are manifested in the knowledge of plants and ways they are used. Interest in wild plants is revitalised today thanks to environmental accents and the need to care for the landscape.
\end{abstract}

\section{Key words}

Wild plants; self-sufficiency; local cuisine; healing 
V současné době můžeme zaznamenat, že téma regionální kuchyně je aktuální, mimo jiné, také $v$ rámci environmentálních diskuzí. Děje se tak, zejména v kontextu lokálních potravin a samozásobitelství. Diskutovány jsou tyto způsoby zajištění potravy formou, která oproti globálnímu potravinářskému průmyslu méně zatěžuje životní prostředí. Právě s regionální kuchyní lokální potravinové zdroje úzce souvisí. Na následujících řádcích se budeme, v tomto kontextu, věnovat planným léčivým rostlinám a planným jedlým rostlinám.

Rozdíly mezi jednotlivými zeměmi a regiony najdeme nejen v náboženství, přírodních podmínkách, umění, atd. Projevují se také v kuchyni. Tomuto tématu se věnuje velké množství studentských prací (zajímavným zpưsobem např. výzkum I. Baláčové, nebo O. Fraňka) i etablovaných badatelů (viz níže).

Pakliže se ptáme, co má vliv na podobu regionální kuchyně, Ize uvést např. klasifikaci socioložky Věry Dvořáková-Janů, která se tématem zabývá. Rozlišuje dvě skupiny faktorů. Na jedné straně př́rodní podmínky (klima, geografie, apod.), na straně druhé podmínky společenské (zahrnující podmínky historické, kulturní, aj.). „Národní a regionální rozdíly hrály vždy ve zpüsobu vaření velkou roli, stejně jako sociální vrstva a náboženství. Př́rodní podmínky na straně jedné a sociální procesy, jež daly vzniknout národním státům a národní identitě, na straně druhé, patř́ k základním přičinám vzniku regionálních specialit a stylů vaření." (Dvořáková-Janů, 1999: 106).

Podobně také Askegaard a Madsen uvádějí podmínky klimatické, geografické, sociální a historické (Askegaard a Madsen in Frewer, Risvik, Schifferstein, 2001: 324). Pitte zase jmenuje jako dva hlavní faktory životní prostředí a kulturu (Pitte, 2002: 12). Obdobně Montanari hovoří o historii a geografii s tím, že identita jídla je produktem spíše historie než geografie. Přesněji řečeno, je produktem geografie ovlivňované historií (Montanari, 2002: 31).

V následujícím textu nás více zajímají podmínky přírodní. Ty se právě výrazně uplatňují v nabídce lokálních potravin a místní kuchyně. Samozřejmě v dobách dřívějších byla závislost kuchyně na přírodních podmínkách patrnější. Marie Úlehlová-Tilschová píše: „O stravě toho či onoho národa rozhodovaly kdysi především př́rodní podmínky. Zeměpisná šířka i nadmořská výška, složení pưdy a podnebí. Ty vtiskly hlavní pečet'stravě kraje. Jinak se živívali lidé $v$ horách než v dolinách, jinak na drsném severu než na teplém jihu.“ (Úlehlová-Tilschová 1997:16).

Dřivě bylo přizpůsobování se přírodním podmínkám přirozené $a v$ podstatě nutné. I v současné době však vidíme trend přizpůsobovat se a podrobovat místním přírodním podmínkám (nejen) $\checkmark$ rámci stravování. Rozdíl oproti dobám minulým je ten, že dnes, díky technickým vymoženostem a pokroku, se přizpůsobovat nutně nemusíme, avšak činíme tak na základě svého rozhodnutí, dobrovolně. Rostoucí globalizace a s ní související standardizace a homogenizace s sebou současně přinesla potřebu autenticity a identity založené na kulturním dědictví, na lokálních tradicích a reinterpretaci jídelních tradic daného regionu. (Valagao, 2002: 33) Lokální potraviny, snaha o zdravý životní styl, samozásobitelství a s tím související snižování ekologické stopy se začíná stávat „pozitivním luxusem“. (Librová 2003). Součástí tohoto trendu je také zájem o lidové léčitelství, plané jedlé divoké rostliny a léčivé byliny.

Pozastavíme-li se nad pojmem „jedlá divoká rostlina" je možné jej definovat tak, že zahrnuje všechny rostliny vhodné $k$ jídlu, aniž by byly záměrně kultivovány. Většinou se jedná o druhy rostoucí $\checkmark$ jejich přirozeném prostředí. (Franěk 2017: 26). Z přibližně tří tisíc pěti set druhů naší přirozené flóry je pro konzumaci vhodných 5\%. Konkrétně se jedná o 175 cévnatých rostlin, 3 lišejníky a 1 mechorost (Simkova a Polesny 2015). Ne všechny tyto druhy jsou ale svým výskytem přirozené pro Českou republiku (Franěk 2017: 26). Z celkového počtu uvedených rostlin je 30 z nich alochtonními organismy - nevyvinuly se samy na daném území, nebo se na něj nedostaly svépomocí (Danihelka a kol. 2012). 
Na základě etnobotanického výzkumu Simkové a Polesneho, kteří zkoumali 37 publikací o historii českého stravování, popisující využívání divokých rostlin od 16. století v českých kuchyních, byl získán podrobný obraz o plevelech jako zdrojích potravy v českých zemích (Franěk 2017: 26). Tyto rostliny mohou být rozděleny do osmi kategorií na základě jejich podobnosti v užívání. Franěk uvádí následující klasifikaci: zelenina (je největší skupinou - do této skupiny patř́ 76 druhů; za nejvíce užívané Ize uvést druhy Urtica dioica, Glechoma hederacea, Rumex spp., Taraxacum sect. ruderalia, Artiplex spp. a Lepidium ssp.), divoké ovoce (sem spadá 26 druhů; jsou to například plody druhů Sambuscus nigra, Rubus caesius L., Corylus avellana, nebo Vaccinium myrtillus), rostliny pro připravu nápojů (např. Rubus idaeus, Fragaria vesca, Cornus mas, Rosa canina, Bellis perennis, Salvia pratensis a Tanaceum vulgare, nebo květy Origanum vulgare), květy (např. Sambuscus nigra, Robinia pseudocacia a Trifolium spp.), podzemní části rostlin (používání kořenů, rhyzomů, cibulí a hlíz je popsáno u 30 druhů planě rostoucích rostlin; Ize uvést např. Acorus calamus, Campanula Rapunculoides L., Phyteuma spicatum L., Arum maculatum L.), semínka (např. Rosa canina a Astragalus Glycyphyllos L., plody Quercus robur a části Vicia sativa byly užívány jako náhražky kakaa a kávy), koření ( $k$ dochucování jídel bylo hojně využíváno plodů Juniperus communis a květů Viola spp. a obzvláště Viola odorata., dále části rostlin Fragaria vesca, Achillea ptarmica a Vaccinium myrtillus), konzervanty (látky obsažené v několika rostlinných druzích je možné požívat jako konzervanty; např. plodící větve Juniperus comunis využívaly pro konzervaci zvěřiny), a poslední skupinu tvoří rostliny s dalším využitím (do této kategorie spadají rostliny využívány pro př́ípravu olejů, mouk, octů a medů; např́klad Hypericum spp., olej extrahovaný z plodů Corylus avellana, atd. Sem Ize zařadit i další druhy, jejichž části byly konzumovány převážně v dobách hladomorů, např. mouky připravené $z$ druhů Arum maculatum. Pro prípravu octů se často využívala Artemisia vulgaris) (Franěk 2017: 28). V následující části se blíže zaměříme na naše plané léčivé rostliny (léčivky, byliny). Rostliny vždy poutaly zájem člověka. A to nejen jako zdroj potravy, ale i jako platforma různých léčebných preparátů. Solecki uvádí, že na základě dochovaných fosilních důkazů Ize usuzovat na to, že lidstvo využívalo byliny jako léčivo již v době středního paleolitu (Solecki 1975).

Aby lidem rostlina dlouho vydržela, sušili její léčivé části - listy, kořeny, nat', květy, plody apod., nebo ji ještě čerstvou konzervovali. $V$ dnešní době takto zpracovanou rostlinu nazýváme drogou (Korbelář-Endris 1981: 18). Tímto se dostáváme $k$ otázce, jaké části léčivých bylin jsou k léčení užívány. Sbírá se většinou část, která obsahuje účinných látek nejvíce. Z nadzemních částí to je nat' (herba), mladý vršek (summitas), lodyha (caulis), pupen (gemma), list (folium), dřevo (lignum), kůra (cortex), květ (flos), plod (fructus), stopka (stipes), semeno (semen), žlázy (glandulae) a výtrusy (sporae). $Z$ podzemních částí rostlin se $k$ léčebným účelům užívá kořen (radix), oddenek (rhizoma), hlíza (tuber) a cibule (bulbus) (Korbelář-Endris 1981: 19).

Dnes zájem o planě rostoucí rostliny, jak bylo řečeno výše, sílí spolu se zájmem o zdravý životní styl, environmentálně přiznivé chování a o alternativní medicínu. Spolu s tím také roste zájem o vědomosti a dovednosti našich předků v této oblasti, o tzv. lidovou léčbu. J osef Čižmář ve své knize Lidové lékařství v Československu objasňuje pojem lidová léčba takto: "Názvem lidová léčba rozumíme souhrn starobylých způsobů léčení v souvislosti s nejstaršími predstavami tajemných nebo neznámých přičin nemocí." (Čižmář 1946: 9). Součástí lidové léčby, podobně jako u většiny směrů alternativní medicíny, byla nejen léčba samotná, ale také prevence nemocí. Ta se v lidovém lékařství prováděla různorodě. Nejen bylinami, ale také například příslovími, pořekladly apod. Ač by se to nemuselo zdát, i jejich podoba souvisela s danou lokalitou, s lokálními materiálními i duchovními zdroji. „Pozornost také naši předkové věnovali amuletům a talismanům, které měly poskytovat nejen ochranu před nemocemi, ale lidé věřili, že je ochrání před duchy a čarami. Důležitou úlohu hrál materiál, z kterého byl amulet vytvořen. $Z$ jeleních parohů se vyráběly prsteny, které měly působit proti křečím, z kovu se zhotovovaly amulety, jež měly nositele chránit před uřknutím." (KorbelářEndris 1981: 18) K léčbě se využívalo také přírodních živlů jako je oheň či voda.

Ochrannou moc a léčebnou sílu hledali lidé samozřejmě také $v$ rostlinách, zejména $v$ těch, které byly na dosah ruky, které jim krajina jejich života nabízela. Tak se napríklad doporučovalo nosit u sebe hledíček neboli světlík lékařský (Euphrasia rostkoviana), čekanku obecnou (Cichorium intybus) a prostřelenec neboli hořec křížatý (Gentiana cruciata). Jmenované byliny měly chránit svého nositele před čarodějnicemi. 
Tyto magické aspekty lidového léčitelství jsou velmi zajímavé, avšak vzhledem k rozsahu i zaměření předkládaného textu se jim již nebudeme dále a hlouběji věnovat. Spíše se krátce zaměřime na historii léčby bylinami. Historie bylin, které se užívaly k léčení, je stará asi šedesát tisíc let. I da Rystonová uvádí, že je to dokonce o osmačtyřicet tisíc let dřive, než lidé poznali obilí. (Šarounová 2013: 20).

Na západní Moravě se léčivým bylinám říkalo beliny, na východní Moravě, Slezsku a Slovensku byly nazývány zeliny (Čižmář 1946: 181). Jak bylo řečeno výše, léčivé rostliny měly široké užití. Nejčastěji se z nich dělaly čaje, odvary nebo lázně, spařovaly se a využívána byla také jejich štáva, kterou se potírala postižená část těla. Lidé si léčivých rostlin vážili a podle toho, jak na ně daná rostlina působila, zda jim poskytovala úlevu či př́ijemně voněla, dávali jim poetická jména. Pojmenování rostlin bylo často $v$ úzkém spojení $s$ jejich účinností (Šarounová 2013: 11). V názvosloví rostlin byl často slovní kořen shodný s kořenem slova, které nejlépe vystihovalo danou vlastnost rostliny, např. ranolica (úročník bolhoj) byla přikládána na rány nebo úplavičník (průtržník lysý) se podával při úplavici. Léčivým bylinám se také dávala jména podle zviřat, která nějak připomínaly (hadí hlava, myší chvost, stračínožka). Jména léčivých bylin často vychází také z křestáanské mytologie. Na tomto místě můžeme jmenovat koření sv. Petra, Kristovu korunu nebo rostlinu zvanou archangelika (Šarounová 2013: 12).

I když léčivá moc rostlin byla využívána již dávno $v$ pravěku, největšímu rozmachu léčení pomocí bylin v Evropě došlo se vznikem herbářů v 16. století. První herbář v českém jazyce se jmenoval Kniha lékařská a byl vydán roku 1517. Byly $v$ něm zachyceny nejen vědomosti a znalosti jejího autora, Jana Černého, ale obsahovala i další informace $z$ tehdejších latinských spisů o této tématice. Nejznámějším herbářem se však, o několik let později, stala kniha Petra Ondřeje Mattioliho, kterou $v$ roce 1562 do češtiny přeložil Tadeáš Hájek z Hájku (Franěk 2017: 30). Magie rostlin, jejich léčebná a účinná síla, o kterou se $v$ dnešní době zajímáme, byla během osvícenství a nástupu racionalismu demytizována a tento proces vyvrcholil s nástupem průmyslové revoluce, která byla spojena i s vývojem organické chemie a fyziologie rostlin. „Tak se s postupem času zjistilo, že na procesy fotosyntetické asimilace $v$ rostlinných tělech navazují další reakce, jejíž produkty vstupují do různých metabolických drah a těmito procesy vznikají sekundární metabolity jako např́klad alkaloidy, fytoncidy, glykosidy a další skupiny obsahující nepřeberné množství látek, které jsou vlastní jen některým druhům rostlin. To vysvětlovalo rozmanitost jejich látek používaných v lidovém léčitelství. S industrializací, modernizací a změnou modu vivendi společnosti se zvětšila i preference k syntetickým farmaceutickým produktům, které byly snadněji získatelné a účinnějš̌̌l" (Franěk 2017: 30). Kouzlo zmizelo, magie rostlin, nadpřirozená síla této části živé prírody byla odhalena, vysvětlena a nahrazena jejich syntetickou podobou. $V$ dnešní době však vidíme opět zájem o planě rostoucí rostliny $v$ podobě, $v$ jaké je Ize nalézt v krajině, v jejich přirozené existenci. Dochází k renesanci zájmu o rostliny, at už jako potraviny nebo léky. Jsou to dvě oblasti, které se významným způsobem překrývají (Pierroni 2000). A proto se téma využívání planě rostoucích rostlin v potravinářství a léčitelství překrývá. (Franěk 2017: 29).

Dle Knotka a kol. (2012) jsou a byly nejčastěji používanými bylinami u nás: máta peprná (Mentha piperita: nevolnost, dýchací obtíže, špatné trávení), meduňka lékařská (Melissa officinalis: křeče, nervové vypětí, nespavost, křeče, bolesti hlavy), lípa srdčitá Tilia cordata chřipka, horečka, angina pectoris, zánět žil), jitrocel kopinatý (Plantago lanceolata: bronchitida, astma, žlučové kameny, hojení ran, bércové vředy, trombóza žil), heřmánek pravý (Matricaria recutita: pocení, vyčerpanost, zánět spojivek, kožní vyrážky, teplota horečka); kopřiva dvoudomá (Urtica dioica: ekzémy, bolest hlavy, pročištění krve, záněty močových cest, onemocnění ledvin); bez černý (Sambucus nigra: nachlazení, zácpa, bolest hlavy, neuritida); šalvěj lékařská (Salvia officinalis: třes končetin, křeče, ztráta chuti k jídlu, krvácení dásní, nadýmání); bříza bělokorá (Betula pendula: revmatismus, nemoci ledvin, snižování cholesterolu, dna); třezalka tečkovaná (Hypericum perforatum: namožení svalů, nespavost, onemocnění nervů, deprese, náměsíčnost, nepravidelnosti periody); proskurník lékařský (Althea officinalis: průdušky, kašel, katary průdušek, žaludeční a dvanácterníkové vředy); růže šípková (Rosa cannina: záněty močového měchýře a ledvin, nachlazení, kašel, horečka, kurděje) (Knotek a kol. 2012). 
Obdobně vypovídá i výzkum provedený I . Krejčovou v roce 2011. Výzkum ukázal jako nejpouživanéjší tyto byliny: heřmánek, máta, meduňka (15\% procent z dotazovaných); šalvěj, kopřiva ( $13 \%$ z dotazovaných); Echinacea, měsíček (12 \% z dotazovaných); lípa (10 \% z dotazovaných); jitrocel, zázvor ( $9 \%$ z dotazovaných); lichořeřišnice, třezalka (7 \% z dotazovaných); bez černý, česnek, konopí ( $6 \%$ z dotazovaných); čajovník, kontryhel, levandule, mateřídouška, ostropestřec, podběl, tymián, ( $5 \%$ z dotazovaných); bazalka, brusinky, cibule, fenykl, hřebíček, jinan, majoránka, řebříček, šípek. Rostliny, které obsadily první příčku, ale i ty, které se umístily na nižších příčkách, pocházejí, až na pár výjimek, z našeho prostředí - většinou jsou to rostliny vyskytující se na území České republiky, které se tedy dají snadno sbírat nebo pěstovat. $V$ některých př́padech se objevily $\mathrm{i}$ rostliny pro naši lokalitu netradiční, jako je např́klad jinan dvoulaločný (gingko biloba), hlíva ústřičná, čajovník, atd. Kromě těchto několika módních a nepůvodních rostlin respondenti uváděli zejména léčivé rostliny, jež jsou u nás doma a které byly užívány již našimi předky.

Předkládaný text byl pouhou sondou, krátkým uvedením do souvislostí mezi člověkem a jeho krajinou, mezi lokální kuchyní a tím, co daný region člověku nabízí. Závěrem Ize říci, že plané rostliny, využitelné $k$ jídlu a léčení hrály důležitou roli v minulosti a dnes se $k$ nim opět vracíme. Nepohližíme na ně však již jen z hlediska jejich léčebných schopností. Fokus, kterým je na ně nahlíženo, se rozširǐil a rozdělil na více složek. Jedním z nich z nich je fokus regionální či národní identity. Důraz na tradiční gastronomii jako kulturní aspekt a způsob hodnocení identity venkovských oblastí nabývá na důležitosti skrze rozpoznávání gastronomie jako kulturního dědictví (Valagao, 2002: 33). Naše země je relativně malá, nabízí však poměrně rozmanité přírodní podmínky. A tak nalézáme rozdíly mezi kuchyněmi horských oblastí, vrchovin nebo třeba úrodných nížin. Rozdíly samozřejmě existuji i v časové ose vývoje jednotlivých regionů. Staročeská kuchyně konce 19. století se v mnohém liší od kuchyně, která se vařila po druhé světové válce, a ta je odlišná od té dnešní.

Dalším významným fokusem nahlížení a přístupu k „divokým“ rostlinám se stává environmentální optika. „Planě rostoucí rostliny mohou sloužit jako nástroje, skrze které jsou někteř́ jednotlivci dnešní společnosti schopni reflektovat socioekonomické a ekologické dění dnešního světa." (Franěk 2017: 86). Využívání planě rostoucích rostlin, které mohou nabývat estetických, ekonomických a dalších hodnot, už není vnímáno jako zpátečnické, naopak, může být označeno za nový trend reflektující vysokou neekologickou spotřebu zboží a služeb dnešním člověkem. (Franěk 2017: 86). S tím souvisí i renesance regionální kuchyně. Montanari ji dává do kontextu s negativními dopady globalizace potravinářského průmyslu (Montanari 2002: 30). U nás je to některými autory interpretováno jako reakce na období socialismu. „Je však možné, že tento fenomén v ČR souvisí se čtyřicetiletou pauzou způsobenou antiburžoazním komunistickým režimem a jedná se tedy spíše o hledání kořenů, tradice" (Geryková, 2009: 13). Toto je jistě důležitý aspekt, avšak je pouze jedním z mnoha důvodů, které se za oživeným zájmem o regionální produkty, at' už duševní, nebo materiální povahy, skrývají. Jsou to nejen důvody socio-ekonomické, ale také historické a zejména dnes, se jako aktuální jeví pohnutky environmentální.

\section{Bibliografie:}

- ASKEgAARD, S. - MADSEN, T.K. in FREWER, L., RISVIK, E., SCHIFFERSTEIN, H. Food, People and Society: a european perspective of consumers' food choices. Berlín: Springer, 2001, s. 324-326.

- BALÁČKOVÁ, I. (2019). Krajina na talǐri. Vztah regionální kuchyně a př́rodních podmínek na príkladu Broumovska. (dipl.práce)

- ČIŽMÁŘ, J. (1946). Lidové lékařství v Českolovensku I. Brno: vyšlo nákladem dětí autora.

- DANI HELKA, J., CHRTEK J r, J., \& KAPLAN, Z. (2012). Checklist of vascular plants of the Czech Republic. Preslia, 84(3), 647-811

- DVOŘÁKOVÁ-JANU゚, V. Lidé a jídlo. 1.vyd. Praha: ISV, 1999, 182 s. ISBN 8085866412. 
- FRANĚK, O. (2017). ETNOBOTANICKÝ HERBÁŘ: Vztahy mezi člověkem a planě rostoucími rostlinami. (dipl. práce)

- GERYKOVÁ, Z. (2009). Environmentální souvislosti luxusní gastronomie. Brno: Masarykova univerzita. (dipl. práce)

- KNOTEK, K., VeRneR, V., CHALOUPKOVA, P., \& KOKOSKA, L. (2012). Prevalence and use of herbal products in the Czech Republic: over-the-counter survey among adult pharmacies clients. Complementary therapies in medicine, 20(4), 199-206.

- KORBELÁŘ, J., ENDRIS Z., (1981). Naše rostliny v lékařství. Praha: Avicenum, zdravotnické nakladatelství.

- KREJČOVÁ, I. ( 2011). Př́rodní medicína jako alternativní způsob léčby obyvatel, aneb návrat ke kořínkưm. (dipl. práce)

- LIBROVÁ, H. (2003). Vlažní a váhaví (kapitoly o ekologickém luxusu). Doplněk.

- MONTANARI, A. Food and environment. Řím: Societa geografica italiana, 2002, s. 29-32.

- MONTANARI, A. Food and environment. Řím: Societa geografica italiana, 2002, s. 33-46.

- PITTE, J-R. Geography of Taste between Globalization and Local Roots. In MONTANARI, A. Food and environment. Řím: Societa geografica italiana, 2002, s. 11-28.

- PIERONI, A. (2000) Medicinal Plants and Food Medicines in The Folk Traditions of Upper Lucca Province Italy. Journal of Ethnopharmacology 70(3): 253-273.

- SIMKOVA, K., POLESNY, Z. (2015). Ethnobotanical review of wild edible plants used in the Czech Republic. Journal of Applied Botany and Food Quality, 88(1).

- SOLECKI, R. S. (1975). Shanidar IV, a Neanderthal flower burial in northern Iraq. Science, 190, 880-881.

- ŠAROUNOVÁ, T. (2013). Vybrané české názvy léčivých rostlin. Brno: Masarykova univerzita. (dipl. práce)

- ÚleHLOVÁ-TILSCHOVÁ, M. (1997). Chutóvý místopis. 2.vyd. Praha: Dita.

- VAlagAO, M-M. The Reinvention of Food Traditions and New Uses of Countryside. In MONTANARI, A. Food and environment. Řím: Societa geografica italiana, 2002, s. 33-46. 